\title{
The Influences of Participatory Management and Corporate Governance on the Reduction of Financial Information Asymmetry: Evidence from Thailand
}

\author{
Pannarai LATA ${ }^{1}$ \\ Received: August 01, 2020 Revised: October 05, 2020 Accepted: October 15, 2020
}

\begin{abstract}
The purposes of this research were: 1) to investigate the effect of participatory management on financial information asymmetry, 2) to investigate the effect of corporate governance on financial information asymmetry, 3) to examine the influences of benefits incentives on financial information asymmetry, and 4) to test the mediating effects of benefits incentive that influences the relationship between participatory management, corporate governance, and financial information asymmetry. The research sample consisted of 388 Thai-listed firms. Data were collected through a survey questionnaire. Descriptive analysis, Multiple Regression Analysis, and Structural Equation Modeling were used for the data analysis. The results revealed: 1) participatory management and participation in evaluation had a negative influence on financial information asymmetry. 2) Corporate governance and the rights of shareholders had a negative influence on financial information asymmetry. 3) Benefits incentive was negatively associated with financial information asymmetry. 4) The model's influences of participatory management, corporate governance on the reduction of financial information asymmetry through benefits incentive as mediator fit the empirical data (Chi-square $=104.459, \mathrm{df}=84, \mathrm{p}=0.065$, GFI $=0.967$, RMSEA $=0.025$ ). The variables in the model explained $78.00 \%$ and $4.70 \%$ of the variance of benefits incentive and financial information asymmetry, respectively.
\end{abstract}

Keywords: Participatory Management, Corporate Governance, Benefits Incentives, Financial Information Asymmetry

JEL Classification Code: M41, M48, D82, G32

\section{Introduction}

Currently, the competition in the world market is more intense and varied. Besides, business organizations are rapidly growing and expanding in both related and unrelated businesses, both domestically and internationally. Integration in the form of holding companies and subsidiaries is very popular among public limited companies. After the merger, both businesses continue to operate independently and are considered to be separate business units under the law.

${ }^{1}$ First Author and Corresponding Author. Accounting Program, Faculty of Business Administration, King Mongkut's University of Technology North Bangkok, Thailand [Postal Address: 1518 Pracharat 1 Road, Wongsawang, Bangsue, Bangkok, 10800, Thailand] Email: pannarai.r@fba.kmutnb.ac.th

(c) Copyright: The Author(s)

This is an Open Access article distributed under the terms of the Creative Commons Attribution Non-Commercial License (https://creativecommons.org/licenses/by-nc/4.0/) which permits unrestricted non-commercial use, distribution, and reproduction in any medium, provided the original work is properly cited.
Reasons for the holding companies to use the method of buying shares in another company are 1) to prevent takeover from competitors 2) to expand the business both horizontally and vertically, increasing the assets, capital, customer base, and creating stability for the business 3 ) to improve operations 4) for tax administration and investment promotion from the government, and 5) to increase investment rights. In the accounting standards, the holding companies (parent company) and subsidiaries are considered the same business unit.

Therefore, the parent company is responsible for preparing the consolidated financial statements. Moreover, when mergers and acquisitions occur, the nature of operations and organizational structure become more complex. At the same time, subsidiaries can manage and operate independently, resulting in the parent company needing to find measures to motivate executives or agents in the subsidiary to work and make decisions under the policies of the parent company. Besides, executives or agents in subsidiaries must report both financial and nonfinancial information to the parent company. However, 
executives or agencies of subsidiaries often have confidential private information that holding companies (parent company) cannot access. Such situations may encourage or allow subordinates to participate in opportunistic, fraud, or corrupt behavior. Financial fraud has become a serious issue for years and attracted the public, press, investors, the financial community, and regulators because of high-profile fraud report at large firms (Cumming, Hornuf, Karami, \& Schweizer, 2020; Abbas, 2017; Vlad, Tulvinschi, \& Chirita, 2011).

Besides, for the business sector, there are still significant problems with fraud in the preparation of financial statements, which is the intentional effort of an entity to deceive users of the financial statements (Brazel, Jones, \& Zimbelman, 2009; Signori \& Vismara, 2018; Hornuf, 2018). Financial fraud is often takes place in various ways, for example counterfeiting documents, evidence of financial transactions, sources of information with intentional misunderstandings, omissions or misrepresentation of accounts, or other important information in the financial statements made. Moreover, there are deliberate offenses regarding the selection of accounting policies and methods used to measure and recognize the value, inadequate disclosure of information, or the presentation of the part that needs to be disclosed, including asset transfer and account adjustment to avoid taxation or personal gain (Rezaee, 2005; Randall, Saurage-Altenloh, \& Osei, 2020). Moreover, opportunities for financial frauds arise because of the information asymmetry which leads to a lack of transparency between third parties (Ndofor, Wesley, \& Priem 2013). The information asymmetry situation often occurs in the industry, which has high complexity (Lata \& Jiraphatthanaponsin, 2018). Information asymmetry produces stronger deleterious effects in inter-organizational. Also, the negative relationship between information sharing and opportunism is weaker in relationships that are more than 6 years old (Tong, \& Crosno, 2016). Agency costs consist of the cost of auditing and preventing fraud, and the incentive costs cause of their agency's effort for the organization. A fundamental objective of incentive-based compensation plans is to motivate individuals to exert efforts to improve performance (Sprinkle, 2000).

In this research, information asymmetry is the firm's subordinates (manager or head of operations) who have more private information or possess confidential information about their area of work and responsibility functions than executives in the parent company, are assumed to use their private information to make decisions in their selfinterests. Information asymmetry is related negatively to performance. Good management, corporate governance, auditing, fraud prevention, and benefits incentives were adopted to solve the problem of opportunistic behavior, fraud, and corruption that may occur in the organization. The cost of agents for auditing and fraud prevention is therefore unavoidable. Besides, there are various incentive costs to encourage executives or agents in subsidiaries to try and work following the parent company with the overall benefits and profits of the organization are the most important. The previous literature review by Chong and Eggleton (2007) found that the interaction between information asymmetry and organizational commitment positively affects managerial performance. They indicated that the information asymmetry has a direct and negative impact on managerial performance. Chong and Law (2016) suggest that the reliance on a high budget-based incentive compensation scheme leads to a higher trust in supervisors, which in turn resulted in higher organizational commitment and improved the subordinate's job performance under the situation of high information asymmetry in an organization. Participation is considered a key principle for sustainable development and risk management (Hedelin, Evers, Alkan-Olsson, \& Jonsson, 2017). Collaborative approach increases trust in the use of information to decision-making and group problem-solving (Ulibarri, 2018; Kimmich, Gallagher, Kopainsky, Dubois, Sovann, Buth \& Brethaut, 2019). Participatory management is important to the administration, also it reduces corruption and financial information asymmetry (Thanathep, 2018). Corporate governance is a set of mechanisms that can solve opportunistic behavior and reduce the agency problem between the shareholders and the management (Gillan, 2006; Bhagat \& Bolton, 2008; Marashdeh, 2014). Benefit incentives cost that is paid to motivate agency or subordinates who have high private information to improve their effort to align with the interests of the principal or their agencies. The previous empirical studies still lack this gap and lack the reduction of the information asymmetry situation and lack to test the mediating effects of benefit incentive that influences the relationship between participatory management, corporate governance, and financial information asymmetry.

Therefore, the key research question is whether participatory management and corporate governance influence the reduction of financial information asymmetry through benefits incentives. Besides, the specific questions include: 1) how do participatory management and each of its dimensions relate to financial information asymmetry? 2) How do corporate governance and each of its dimensions relate to financial information asymmetry? 3) How do Benefits Incentive and each of its dimensions relate to financial information asymmetry? Also, the specific research purposes are as follows: 1) to investigate the effect of participatory management and its dimensions on financial information asymmetry, 2) to investigate the effect of corporate governance on and its dimensions on financial information asymmetry, 3) to examine the influences of benefit incentives and its dimensions on financial information asymmetry, 4) to test the mediating effects of benefits incentive that influence the relationship between 
participatory management, corporate governance, and financial information asymmetry. The research sample consisted of 388 Thai-listed firms.

\section{Theoretical Foundations}

Agency theory and stakeholder theory were used to describe the situation and understand the relationship between variables in the conceptual framework.

The theoretical relationship among participatory management, corporate governance, benefits incentives, and financial information asymmetry is explained by the agency theory. Jensen and Mackling (1976) developed this theory to describe the relationship between two parties as principals (stakeholders or top managers) and agents (subordinate). Both have a relationship in reciprocal contractual view. Jensen and Mackling (1976) indicated that principals are responsible for supporting in money or other resources for operating in the firm and then they expect to receive the maximum returns from their resources invested with the firm as well. Furthermore, principals hire agents to perform some services and delegate their decision-making authority to agents, and then agents receive wages or salaries as a reward. Thus, both parties have a conflict of interest or an agency problem. The agency problem is divided into two issues: (a) adverse selection is the condition that principals cannot ensure the agents' ability to manage, and (b) moral hazard is the condition that principals cannot ensure agents' behavior about working at maximum effort and maximum principals' benefits. These problems occur because both parties have information asymmetry. Agents have more information than principals while principals cannot observe the agent's optimistic behavior all the time. Therefore, principals suspect whether agents work to maximize the principal's wealth. Markl-Davis and Brennan (2007) further clarified that agency theory can split the behavior of agents (or subordinates) into two aspects, consisting of negative and positive assumptions. The negative assumption believes that agents (subordinates) who have opportunistic behavior from information asymmetry problems would provide incorrect information to stakeholders and benefit themselves. In consequence, this negative assumption would have a more serious negative impact on organizational performance (Spindler, 2012). On contrary, the positive assumption believes that agents (or subordinates) provide additional information for reducing the information asymmetry problem and increasing the useful information for stakeholders to make decisions.

Moreover, stakeholder theory was presented by Freeman (1984) who was the first scholar to offer the stakeholder model by demonstrating accountability to various groups of stakeholders. The theory claims that a firm should create value for all stakeholders, not just shareholders. Additionally, the role responsibilities to employees, societies, environment, and communities as well as our shareholders have been discussed. Likewise, Mori (2010) viewed that stakeholder groups are those who are directly affected, either positively or negatively by an organization's actions. The first group that would be directly affected is a group of stakeholders that are important to the survival of the business, including owners, shareholders, customers, employees, communities, and governments, also, it may include other groups such as suppliers of goods and services for the company and creditors. A second group is a group of stakeholders that do not affect the survival but affect the business operations. However, the development of the stakeholder theory has two related streams; first, the concept of stakeholders and second, classifying stakeholders that are relevant to the understanding of individual stakeholder relationships (Rowley, 1997).

Stakeholder theory has been developed to reform the system of corporate governance of public companies. This system is divided into three main assumptions which are 1) all stakeholder have the right to participate in the corporate decisions that affect them, 2) managers as trustees ought to serve the interests of all the stakeholder groups, and 3) the objective of the firm ought to be the promotion of all interests and not those of shareholders alone. Thorne, Mahoney, and Manetti, (2014) argued that insiders know more about a company than investors do; therefore, investors will protect themselves by offering a lower price for the firm. Connelly, Certo, Ireland, and Reutzel (2011) supported that the value of the firm can be increased if the firm voluntarily reports that signals private information about itself is credible and reduces outsider uncertainty. Therefore, the interests of all stakeholders ought to be taken into account in corporate decision-making. Previous research into stakeholder theory has generally focused on the characteristics and the behavior of the organizations. Specifically, stakeholder theory is the most relevant to the analysis of corporate governance (Laan, 2009), stakeholders demand integrity, respect, standards, transparency, and accountability. Therefore, the organization needs to understand the demands and concerns of each group of stakeholders because the stakeholder is necessary for business practices. Thus, the stakeholder theory is used to design corporate governance under a high information asymmetry situation to increase transparency and reduce corruption in Thai-listed firms.

\section{Literature Review and Hypotheses Development}

In this research, participatory management and corporate governance are the primary variables that influence the reduction of financial information asymmetry through the mediating function of benefit incentives. Figure 1 shows the conceptual model in this research. 


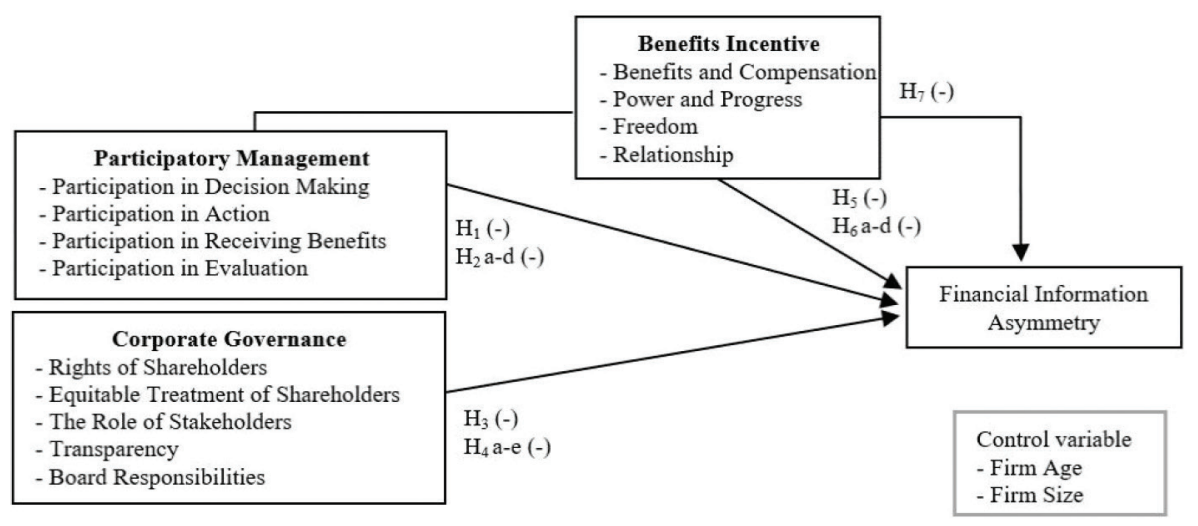

Figure 1: Conceptual model

\subsection{Participatory Management}

Participatory management refers to the operational processes between supervisors and subordinates which involve the process of analyzing, expressing, and making decisions on important matters of management within the organization. The decisions are based on the consistent division of duties, defining objectives or common goals, freedom in responsible work by using creativity within the framework of the job and using knowledge and expertise to help solve the problems of organization, participation in the policy and activities of the organization by the ties of the organization. Participatory management consists of 4 components which are participation in decision making, participation in action, participation in receiving benefits, and participation in evaluation. Participation in decision making is a perspective about the involvement of personnel in the planning process, the thinking process, and the ability to make decisions in group meetings and joining a committee for important work. Participation in action provides a viewpoint of personnel who bring project plans, policies, or guidelines set by the parent companies to actual work, as well as supporters of human resources, equipment, and tools to achieve the goal. Participation in receiving benefits means that executives and employees are involved in receiving benefits from the organizational operations, both positively and negatively. Participation in evaluation is the organization assigning duties to executives in the organization both personally and in the form of committees involved in tracking tasks, providing recommendations for the organizational operations, and supporting activities, also reporting information for all personnel in the organization to recognize and providing feedback to improve work processes.

The relationship between participatory management and financial information asymmetry in the literature review revealed that social support and information shared via official networking are both critical to knowledge creation, decision-making quality, and reduce opportunism and information asymmetry (Joe, 2010). Stakeholder participation is considered a key principle for sustainable development and risk management (Hedelin, Evers, Alkan-Olsson, \& Jonsson, 2017). Collaborative approach increases trust in the use of information for decision-making, and group problem-solving (Ulibarri, 2018). Participants showed significantly more optimism toward increased income, and development planning procedures. Moreover, participatory approach could contribute in making collective solutions and institutionalized agreements (Kimmich, Gallagher, Kopainsky, Dubois, Sovann, Buth, \& Brethaut, 2019). Participatory management and organizational commitment improve organizational performance (Shagholi, Hussin, Siraj, Naimie, Assadzadeh, \& Moayedi, 2010). Employee participation in decision making and problem-solving contributes to high performance and innovation (Fernandez \& Moldogaziev, 2013; Wang \& Yang, 2015). Cooperative management is related to internal auditing effectiveness (Potjanat, 2013). Participatory management reduces corruption in an organization (Thanathep, 2018). Therefore, it could be concluded that participatory management was negatively associated with financial information asymmetry. Hence, the hypotheses are proposed as follows:

H1: The higher the participatory management, higher the likelihood that the firm will reduce greater financial information asymmetry.

$\boldsymbol{H} \mathbf{2 a}-\boldsymbol{d}$ : The dimensions of participatory management including (a) participation in decision making, (b) participation in action, (c) participation in receiving benefits, and (d) participation in evaluation lead to a negative influence on financial information asymmetry.

\subsection{Corporate Governance}

Corporate governance is defined as the relationship management of systems, structures, and processes of the board 
of directors, management, shareholders, and other stakeholders to create competitiveness, lead to growth and add value to the shareholders in the long term, with consideration to other stakeholders. Corporate governance consists of 5 perspectives, including the rights of shareholders, the equitable treatment of shareholders, the role of stakeholders, transparency, and board responsibilities, respectively. Rights of shareholders are the perspective of shareholders who have ownership rights by controlling the company through a committee appointed to act on their behalf and have the right to make decisions about important changes to the firms, in which shareholders may have roles both executive and non-executive, majority and minority shareholders, including foreign shareholders, all must be treated equally and fairly by the firms. Equitable treatment of shareholders is that firm's shareholders have equal rights in the firm and there is a need to use a policy of governance for all shareholders, which means that all the shareholders - executive shareholders, non-executive shareholders, and foreign shareholders should be treated equally and fairly by following the rule of the law. The role of stakeholders is stakeholders should be cared for by the firm under their legal rights.

The board of directors should consider the process of promoting cooperation between the firm and the stakeholders in creating financial wealth and sustainability under the corporate governance system. Transparency can be defined as individual and organizational actions that can be seen, are predictable, and can be understood by all the actions that result from the management decisions to business operations, and various public works, including having transparent work systems and procedures. Board responsibilities are the use of various knowledge, skills, and experiences in work, independent judgment, leadership, and the responsibility to define the strategy, direction, policy, goals, and mission of the company so that executives and employees aim to operate in the same direction. Jantadej and Wattanatorn (2020) found that the corporate governance affects the cost of debt. The relationship between corporate governance and financial information asymmetry in the literature review revealed that good corporate governance and risk management is positively related to financial reporting quality (Hafez, 2015). Corporate governance protects investors and executives from opportunistic behavior (Gillan, 2006; Bhagat \& Bolton, 2008). Corporate governance mechanisms can solve the agency problem between shareholders and management (Marashdeh, 2014). Corporate disclosures affect information asymmetry (Ajina, Sougne, \& Lakhal, 2015). Nel, Smit, and Brummer (2018) found a significant negative association between disclosure vehicles in the annual report and information asymmetry. Thus, it could be concluded that corporate governance was negatively associated with financial information asymmetry. Hence, the hypotheses are proposed as follows:
H3: The higher the corporate governance, the more likely that the firm will reduce greater financial information asymmetry.

H4a-e: The dimensions of corporate governance including (a) rights of shareholders, (b) equitable treatment of shareholders, (c) the role of stakeholders, (d) transparency, and (e) board responsibilities have a negative influence on financial information asymmetry.

\subsection{Benefits Incentive}

Benefits incentive is defined as the extent to which they pay incentives (such as bonus or profit-sharing) are used as the compensation strategy or scheme in an organization (Balkin \& Gomez-Mejia, 1990; Chong and Law, 2016; Sprinkle, 2000). Dimensions of benefits incentive include the first dimension as "benefits and compensation" which is the wage, compensation, or other benefits for sustaining and improving the quality of life of the personnel in an organization under fairness and suitability for workability, as well as, leading a life without trouble. The second dimension is "power and progress" which is defined as plans or supporting policies regarding the progress and authority of the subordinates, opportunities for future job development and positions, and power to manage work in their own departments, subsidiary firms, or subsection that supervised them. The third is "freedom" on the assignment that each department is responsible for working unconditionally but within the scope of the organization's rules, as well as for allowing all the sectors to express opinions, accept opinions, and apply ideas as part of the organizational improvements, and establishing an uncomplicated organizational structure to reduce administrative steps. The perspective of relationship is the fourth dimension that refers to the needs and expectations of good interaction from executives, colleagues, and subordinates, for the best relationship of assistance and advice to work efficiently among themselves because the organization has valued and accepted personnel.

Opportunities for financial reporting fraud arises because of the information asymmetry between subordinates and their shareholders or their superiors (Ndofor, Wesley \& Priem, 2013). The firm must find how to obtain valuable and unique local information from subordinates willingly. Relying on agency theory, it is argued that a high reliance on incentive-based compensation schemes is more appropriate when information asymmetry is high rather than low. Agency theory posits that the principal can minimize moral hazard problems by developing an incentive-based compensation scheme that aligns the interests of principal and agent, in this study is the interests of subordinates and their superiors. The previous literature review supports the view that reliance on incentive-based compensation schemes has a positive 
effect on individual performance by stimulating a higher level of subordinates' effort (Chong \& Eggleton, 2007). Chong and Law (2016) have found that the reliance on a high budget-based incentive compensation scheme leads to a higher trust-in supervisor, which in turn results in higher organizational commitment and improved performance. It also creates a positive relationship between information asymmetry, performance, and trust (Tong \& Crosno, 2016). Thus, the relationships are hypothesized as follows:

H5: The higher the benefits incentive is, the more likely that firm will reduce greater financial information asymmetry.

H6a-d: The dimensions of benefits incentive including (a) benefits and compensation, (b) power and progress, (c) freedom, and (d) relationship have a negative influence on financial information asymmetry.

H7: Participatory management and corporate governance are negatively associated with financial information asymmetry through benefits incentives as a partial mediator.

\subsection{Financial Information Asymmetry}

Financial information asymmetry is defined as the firm's subordinates (manager or head of operations) have more private information or possesses confidential information about their task area and responsibility functions than their top managers in the holding company. Moreover, private information contains segment information, internal management information, and personal information (Chong \& Law, 2016; Lata \& Jiraphatthanaponsin, 2018; Ndofor, Wesley, \& Priem, 2013). In detail, segment information is the possession of information about budgets, financials, accounting, assets, liabilities, profit and loss, expenses in subsidiaries, both for disclosure as required by the standards and for the internal management, etc. Internal management information refers to the acquisition and access to information regarding human resource management, decision making on new staffing, staff promotion, and recruiting suppliers, service providers, and contractors, etc.

Lastly, personal information is private information of the individual's unique knowledge caused by deep intuition, experience, belief, learning, or creativity in work. Knowledge arises through observation, training, and dialogue. This knowledge is difficult to share but can be transferred to gain administrative advantages for the organization. The subordinates possess more private information about their task environment than their superior, presumably they could be using this private information to make decisions for their self-interests. The existence of more private information is an illustration of information asymmetry between subordinates in subsidiaries and top managers in holding company. Consequently, it is argued that high information asymmetry, dysfunctional behaviors are more likely to occur when low information asymmetry is based on agency theory. On the other hand, the positive assumption in agency theory believes that subordinates have more private information about their responsible work, as a result, would provide the firm additional and useful information for the decision making purpose of the top managers in the future. Hence, the parent company must only motivate subordinates to work following the parent company policy to prevent corruption in the organization. Nel, Smit, and Brummer (2018) indicated that information asymmetry manifests when one party has more information than the other.

\section{Research Methods}

\subsection{Sample and Data Collection}

Thai-listed firms, chosen from the database of the Stock Exchange of Thailand (SET) amounts to 749 firms, are used as the population of this research. Thai-listed firms play an important role in enhancing economic growth and stability in Thailand. The research sample consists of 388 Thai-listed firms. The chosen key informant are the executives of each Thai-listed firm. The questionnaires were mailed out on June 15,2019 , to Thai-listed firms accompanied by a cover letter outlining the rationale and aims of this research. A total of 390 returned questionnaires were received, but there were only 388 complete and usable questionnaires. The effective response rate was approximately 52 percent. Moreover, the non-response bias was tested for generalization based on Armstrong and Overton (1977) to test the significant differences of the demographic of firm characteristics (the period of time registered in SET, the period of time in operating business, authorized capitals, the total assets of the firm, and average revenues per year) between 194 early respondents (the first group) and 194 late respondents (the second group). The result of the t-test comparison provides the evidence that there are no statistically significant differences between the two groups at a $95 \%$ confidence level. Thus, it can be confidently mentioned that non-response bias is not a serious problem in this research (Armstrong \& Overton, 1977).

\subsection{Measurement}

Measurement of each construct in the conceptual model, all variables in Table 1 are anchored by a five-point Likert scale (1: strongly disagree, 5: strongly agree) without control variables. Moreover, all constructs are developed for measuring from the definition of each construct and examined the relationship between theoretical frameworks and prior literature reviews. Thus, the measurement of the variables of the dependent variable, independent variables, 
mediating variables, and control variables of this study can be described as follows:

\subsubsection{Dependent Variable}

Financial information asymmetry is measured by the thirty-items scale in three dimensions which involves the key information asymmetries consisting of segment disclosures, internal management information, and personal information. The construct of this variable was developed by new question items based on its definition and theory.

\subsubsection{Independent Variables}

Participatory management is measured by the twenty-items scale in four dimensions which involves the key participatory management consisting of participation in decision making, participation in action, participation in receiving benefits, and participation in evaluation. The construct of this variable was developed by new question items based on its definition and theory.

Corporate governance is measured by the thirty-items scale in five dimensions which involves the key governances consisting of rights of shareholders, the equitable treatment of shareholders, the role of stakeholders, transparency, and board responsibilities. The construct of this variable was developed by new question items based on its definition and theory.

\subsubsection{Mediating Variables}

Benefits incentive is measured by the twenty-item scale in four dimensions which involves the key incentives consisting of benefits and compensation, power and progress, freedom, and relationship. The construct of this variable was developed by new question items based on its definition and theory.

\subsubsection{Control Variables}

The control variables may affect the relationship between the independent variable and dependent variable so firm age (FA), and firm size (FS) are the control variables of this study (Phornlaphatrachakorn \& Peemanee, 2020). Firm size is measured by total assets of the firm, which is a dummy variable $\quad(0=$ total assets of the firm is below or equal to $500,000,000$ baht, $1=$ total assets of the firm that higher than $500,000,000$ baht). And firm age is measured by the duration in business (Phornlaphatrachakorn \& Na-Kalasindhu, 2020) by $0=$ below or equal to 10 years, $1=$ higher than 10 years.

\subsection{Reliability and Validity}

Three academic experts who have experience in this area reviewed the instrument to ensure that the questionnaires use suitable wordings, and all constructs are adequate to cover the content of the variables. Then, the pre-test is conducted with the first 30 returned questionnaires. Reliability was tested by Cronbach alpha to measure the internal consistency of respondents' answers for all items in the questionnaires. Table 1 presents an alpha coefficient that is higher than 0.70 , and the coefficients should have a value greater than 0.70 (Nunnally \& Bernstein, 1994). The constructs' participatory management, corporate governance, benefits incentive, and financial information asymmetry have the highest reliability coefficients $\alpha$ with values $0.93,0.98$, 0.96 , and 0.97 , respectively. Alpha coefficients of constructs have values ranging from 0.71 to 0.96 , the lowest coefficient for participation in action, and the highest coefficient for segment disclosures.

Factor analysis was used to determine the key dimensions in the variables of the participatory management, corporate governance, benefits incentive, financial information asymmetry constructs. The range of factor loadings by EFA and CFA is between 0.566-0.968. These values are greater than the cut-off score of 0.4 to indicate acceptable construct validity (Hair et al., 2010). It ensures the validity and reliability of the questionnaires (Table 1 ).

\subsection{Statistic Test}

Multiple regression analysis is used to test hypotheses 1 to 6 in which all variables are categorical and with interval data by Hair et al. (2010). Thus, all proposed hypotheses transform into 6 statistical equations as follows.

$$
\begin{aligned}
& \text { Equation 1: }=\alpha_{1}+\beta_{1} P M+\beta_{2} F S+\beta_{3} F A+\varepsilon_{1} \\
& \text { FTA }
\end{aligned}
$$

$$
\begin{aligned}
\text { Equation } 2:= & \alpha_{2}+\beta_{4} P D M+\beta_{5} P I A+\beta_{6} P R B \\
& +\beta_{7} P I E+\beta_{8} F S+\beta_{9} F A+\varepsilon_{2}
\end{aligned}
$$

Equation $3:=\alpha_{3}+\beta_{11} C G+\beta_{12} F S+\beta_{13} F A+\varepsilon_{3}$

$$
\text { FTA }
$$$$
\begin{aligned}
\text { Equation } 4:= & \alpha_{4}+\beta_{14} R O S+\beta_{15} E T S+\beta_{16} R S H \\
& +\beta_{17} T S C+\beta_{18} B R B+\beta_{19} F S+\beta_{20} F A \\
& +\varepsilon_{4}
\end{aligned}
$$

Equation 5: $=\alpha_{5}+\beta_{21} B I+\beta_{22} F S+\beta_{23} F A+\varepsilon_{5}$ FTA

$\begin{aligned} \text { Equation 6: }= & \alpha_{6}+\beta_{24} B A C+\beta_{25} P A P+\beta_{26} F R D \\ & \text { FTA } \\ & +\beta_{27} R L S+\beta_{28} F S+\beta_{25} F A+\varepsilon\end{aligned}$ 
Table 1: Results of Validity and Reliability Testing

\begin{tabular}{|c|c|c|c|c|}
\hline Constructs & Variables & items & $\begin{array}{c}\text { Validity } \\
\text { (Factor Loadings) }\end{array}$ & $\begin{array}{c}\text { Reliability } \\
\text { (Cronbach Alpha) }\end{array}$ \\
\hline \multirow{5}{*}{$\begin{array}{l}\text { Participatory } \\
\text { Management } \\
\text { (PM) }\end{array}$} & & 20 & $0.743-0.899$ & 0.93 \\
\hline & Participation in Decision Making (PDM) & 5 & $0.768-0.856$ & 0.81 \\
\hline & Participation in Action (PIA) & 6 & $0.757-0.818$ & 0.71 \\
\hline & Participation in Receiving Benefits (PRB) & 5 & $0.800-0.878$ & 0.84 \\
\hline & Participation in Evaluation (PIE) & 4 & $0.852-0.872$ & 0.89 \\
\hline \multirow{6}{*}{$\begin{array}{l}\text { Corporate } \\
\text { Governance } \\
\text { (CG) }\end{array}$} & & 30 & $0.752-0.920$ & 0.98 \\
\hline & Rights of Shareholders (ROS) & 5 & $0.840-0.894$ & 0.90 \\
\hline & Equitable Treatment of Shareholders (ETS) & 5 & $0.789-0.902$ & 0.93 \\
\hline & The Role of Stakeholders (RSH) & 6 & $0.821-0.880$ & 0.92 \\
\hline & Transparency (TCS) & 8 & $0.743-0.810$ & 0.94 \\
\hline & Board Responsibilities (BRB) & 6 & $0.738-0.851$ & 0.89 \\
\hline \multirow{5}{*}{$\begin{array}{l}\text { Benefits Incentive } \\
\text { (BI) }\end{array}$} & & 20 & $0.728-0.968$ & 0.96 \\
\hline & Benefits and Compensation (BAC) & 5 & $0.829-0.903$ & 0.92 \\
\hline & Power and Progress (PAP) & 5 & $0.813-0.886$ & 0.90 \\
\hline & Freedom (FRD) & 5 & $0.667-0.889$ & 0.86 \\
\hline & Relationship (RLS) & 5 & $0.817-0.896$ & 0.91 \\
\hline \multirow{4}{*}{$\begin{array}{l}\text { Financial } \\
\text { Information } \\
\text { Asymmetry } \\
\text { (FTA) }\end{array}$} & & 30 & $0.566-0.960$ & 0.97 \\
\hline & Segment Disclosures (SDS) & 10 & $0.823-0.893$ & 0.96 \\
\hline & Internal Management Information (IMI) & 12 & $0.749-0.860$ & 0.93 \\
\hline & Personal Information (PSI) & 8 & $0.756-0.870$ & 0.91 \\
\hline
\end{tabular}

\section{Research Findings}

Table 2 shows descriptive statistics (means and standard deviations) and the inter-factor correlation matrix for all variables to evaluate the significance level of the relationships. The correlation analysis highlights the relationships between the independent and dependent variables examined in this research. The relationship between financial information asymmetry and participatory management of ratings is considered as significant at the $0.05(\mathrm{r}=-0.112)$, corporate governance of ratings is considered as significant at the $0.05(\mathrm{r}=0.172)$, benefits incentive of ratings is considered as significant at the 0.05 $(\mathrm{r}=-0.120)$, respectively. Examination of the correlation matrix shows that there were significant and positive linear associations among factors representing the variables such as participatory management $(0.662-0.899)$, corporate governance $(0.691-0.906)$, and benefits incentive $(0.617$ 0.858). While potential problems relate to multicollinearity, variance inflation factors (VIF) are used to provide information on the relationship between the independent variables. This study has VIFs range from 1.013 to 3.865 , well below the cut-off value of 10 as recommended by Hair et al. (2010) and Neter, Wasserman, and Kutner (1989), meaning the independent variables are not correlated with each other. Thus, there are no multicollinearity problems encountered in this research.

\subsection{Multiple Regression Analysis}

In Table 3, the regression analysis results of hypothesis 1 indicated the finding that participatory management has a strong and negative effect on financial information asymmetry $\left(\beta_{1}=-0.112, \mathrm{p}<0.05\right)$. This finding was consistent with Thanathep (2018) who found that participatory management reduces corruption in the organization. Likewise, participation is a key principle for risk management (Hedelin et al, 2017). Collaborative increases trust in the use of information to decision-making and group problem-solving (Ulibarri, 2018). Moreover, the finding to test hypothesis 2a-d indicated four dimensions of participatory management (including participation in decision making, participation in action, participation in receiving benefits, and participation in evaluation) influenced financial information asymmetry. In model 2, the results showed that participation in evaluation significantly and negatively influences financial information asymmetry $\left(\mathrm{H} 2 \mathrm{~d} ; \beta_{7}=-0.223, \mathrm{p}<0.05\right)$. This finding was consistent with Wang and Yang (2015) found that employee participation in processing, decision making, and problemsolving contributes to high performance and innovation. Thus, hypotheses 1 and $2 \mathrm{~d}$ were strongly supported. 
Table 2: Descriptive Statistics and Correlation Matrix

\begin{tabular}{|c|c|c|c|c|c|c|}
\hline Variables & $\begin{array}{c}\text { Financial } \\
\text { Information } \\
\text { Asymmetry (FTA) }\end{array}$ & $\begin{array}{l}\text { Participatory } \\
\text { Management } \\
\text { (PM) }\end{array}$ & $\begin{array}{l}\text { Corporate } \\
\text { Governance } \\
\text { (CG) }\end{array}$ & $\begin{array}{l}\text { Benefits } \\
\text { Incentive } \\
\text { (BI) }\end{array}$ & $\begin{array}{l}\text { Firm Age } \\
\quad \text { (FA) }\end{array}$ & $\begin{array}{c}\text { Firm } \\
\text { Size (FS) }\end{array}$ \\
\hline Mean & 4.17 & 4.14 & 4.10 & 4.13 & $\mathrm{n} / \mathrm{a}$ & $\mathrm{n} / \mathrm{a}$ \\
\hline S.D. & 0.51 & 0.59 & 0.62 & 0.57 & $\mathrm{n} / \mathrm{a}$ & $\mathrm{n} / \mathrm{a}$ \\
\hline $\begin{array}{l}\text { Financial Information } \\
\text { Asymmetry (FTA) }\end{array}$ & 1 & & & & & \\
\hline $\begin{array}{l}\text { Participatory } \\
\text { Management (PM) }\end{array}$ & $-0.112^{*}$ & 1 & & & & \\
\hline $\begin{array}{l}\text { Corporate Governance } \\
\text { (CG) }\end{array}$ & $0.172^{* *}$ & -0.046 & 1 & & & \\
\hline Benefits Incentive (BI) & $-0.120^{*}$ & $0.765^{* *}$ & -0.039 & 1 & & \\
\hline Firm Age (FA) & -0.097 & -0.003 & -0.066 & -0.043 & 1 & \\
\hline Firm Size (FS) & -0.023 & 0.060 & 0.044 & 0.031 & $0.102^{*}$ & 1 \\
\hline
\end{tabular}

${ }^{*} p<0.05,{ }^{* *} p<0.01$

Table 3: Results of Multiple Regression Analysis

\begin{tabular}{|c|c|c|c|c|c|c|}
\hline \multirow{3}{*}{ Independent Variables } & \multicolumn{6}{|c|}{ Dependent Variable } \\
\hline & \multicolumn{6}{|c|}{ Financial Information Asymmetry } \\
\hline & (Model 1) & (Model 2) & (Model 3) & (Model 4) & (Model 5) & (Model 6) \\
\hline \multirow{2}{*}{ Constant } & 0.322 & 0.295 & 0.338 & 0.356 & 0.345 & 0.341 \\
\hline & $(0.232)$ & $(0.232)$ & $(0.231)$ & $(0.230)$ & $(0.231)$ & $(0.231)$ \\
\hline \multirow{2}{*}{ Participatory Management (H1) } & $-0.112^{* *}$ & & & & & \\
\hline & $(0.051)$ & & & & & \\
\hline \multirow{2}{*}{$\begin{array}{l}\text { Participation in Decision Making } \\
(\mathrm{H} 2 \mathrm{a})\end{array}$} & & 0.103 & & & & \\
\hline & & $(0.084)$ & & & & \\
\hline \multirow{2}{*}{ Participation in Action ( $\mathrm{H} 2 \mathrm{~b})$} & & -0.086 & & & & \\
\hline & & $(0.079)$ & & & & \\
\hline \multirow{2}{*}{$\begin{array}{l}\text { Participation in Receiving Benefits } \\
(\mathrm{H} 2 \mathrm{c})\end{array}$} & & 0.080 & & & & \\
\hline & & $(0.090)$ & & & & \\
\hline \multirow{2}{*}{ Participation in Evaluation $(\mathrm{H} 2 \mathrm{~d})$} & & $-0.223^{* *}$ & & & & \\
\hline & & $(0.094)$ & & & & \\
\hline \multirow{2}{*}{ Corporate Governance (H3) } & & & $0.168^{* * *}$ & & & \\
\hline & & & $(0.051)$ & & & \\
\hline \multirow{2}{*}{ Rights of Shareholders $(\mathrm{H} 4 \mathrm{a})$} & & & & $-0.169^{*}$ & & \\
\hline & & & & $(0.096)$ & & \\
\hline \multirow{2}{*}{$\begin{array}{l}\text { Equitable Treatment of Shareholders } \\
(\mathrm{H} 4 \mathrm{~b})\end{array}$} & & & & $0.328^{* * *}$ & & \\
\hline & & & & $(0.098)$ & & \\
\hline \multirow{2}{*}{ The Role of Stakeholders (H4c) } & & & & 0.072 & & \\
\hline & & & & $(0.096)$ & & \\
\hline \multirow{2}{*}{ Transparency $(\mathrm{H} 4 \mathrm{~d})$} & & & & -0.083 & & \\
\hline & & & & $(0.087)$ & & \\
\hline
\end{tabular}


Table 3: Continued

\begin{tabular}{|c|c|c|c|c|c|c|}
\hline \multirow{2}{*}{ Board Responsibilities (H4e) } & & & & 0.039 & & \\
\hline & & & & $(0.079)$ & & \\
\hline \multirow{2}{*}{ Benefits Incentive (H5) } & & & & & $-0.124^{* *}$ & \\
\hline & & & & & $(0.050)$ & \\
\hline \multirow{2}{*}{ Benefits and Compensation $(\mathrm{H} 6 \mathrm{a})$} & & & & & & $-0.165^{* *}$ \\
\hline & & & & & & $(0.076)$ \\
\hline \multirow{2}{*}{ Power and Progress (H6b) } & & & & & & $0.142^{*}$ \\
\hline & & & & & & $(0.079)$ \\
\hline \multirow{2}{*}{ Freedom (H6c) } & & & & & & -0.114 \\
\hline & & & & & & $(0.077)$ \\
\hline \multirow{2}{*}{ Relationship (H6d) } & & & & & & -0.071 \\
\hline & & & & & & $(0.072)$ \\
\hline \multicolumn{7}{|l|}{ Control variables: } \\
\hline \multirow{2}{*}{ Firm Age (FA) } & $-0.194^{*}$ & $-0.174^{\star}$ & $-0.169^{*}$ & -0.164 & $-0.203^{* *}$ & $-0.200^{* *}$ \\
\hline & $(0.102)$ & $(0.102)$ & $(0.102)$ & $(0.101)$ & $(0.102)$ & $(0.102)$ \\
\hline \multirow{2}{*}{ Firm Size (FS) } & -0.014 & -0.016 & -0.047 & -0.061 & -0.019 & -0.019 \\
\hline & $(0.108)$ & $(0.108)$ & $(0.108)$ & $(0.108)$ & $(0.108)$ & $(0.108)$ \\
\hline $\mathrm{F}$ & 2.895 & 2.541 & 4.945 & 2.541 & 3.261 & 2.473 \\
\hline $\mathrm{R}^{2}$ & 0.022 & 0.038 & 0.037 & 0.038 & 0.025 & 0.044 \\
\hline Adjusted $\mathrm{R}^{2}$ & 0.014 & 0.023 & 0.030 & 0.023 & 0.017 & 0.026 \\
\hline Maximum VIF & 1.014 & 3.473 & 1.017 & 3.865 & 1.013 & 2.496 \\
\hline
\end{tabular}

${ }^{* * *} p<0.01,{ }^{* *} p<0.05,{ }^{*} p<0.10$, Beta coefficients with standard errors in parenthesis

Furthermore, corporate governance significantly and positively affects financial information asymmetry $\left(\beta_{11}=\right.$ $0.168, \mathrm{p}<0.01$ ) in model 3. Therefore, hypothesis 3 was not supported. However, the finding to test hypothesis 4a-e indicated five dimensions of corporate governance (including rights of shareholders, the equitable treatment of shareholders, the role of stakeholders, transparency, and board responsibilities) had a negative influence on financial information asymmetry. In model 4 , the results show that the rights of shareholders significantly and negatively influenced financial information asymmetry $\left(\mathrm{H} 4 \mathrm{a} ; \beta_{14}=-0.169, \mathrm{p}<0.10\right)$. Hafez (2015) showed that good corporate governance and risk management positively related to financial reporting quality. Corporate governance mechanisms protected from the opportunistic behavior of executives (Bhagat \& Bolton, 2008). Corporate governance solves the agency problem (Marashdeh, 2014). Corporate disclosures reduce information asymmetry between agencies and principle (Ajina, Sougne, \& Lakhal, 2015). Hence, hypothesis 4a was supported.

Thirdly, regression results in model 5 supported that benefits incentive has a negative influence on financial information asymmetry $\left(\beta_{21}=-0.124, \mathrm{p}<0.05\right)$ which is consistent with Chong and Law (2016) who found that the reliance on a high budget-based incentive compensation scheme leads to higher trust-in agencies. Besides, Lata and Jiraphatthanaponsin, (2018) found that incentives cost that is paid to motivate agency or subordinates who have high private information or information asymmetry to improve their effort aligns with the interests of the principal or their stakeholders. Additionally, the finding to test hypothesis 6a-d indicated that four dimensions of benefits incentive (benefits and compensation, power and progress, freedom, and relationship) affect financial information asymmetry. In model 6, the results showed that the benefits and compensation have a significant and negative influence on financial information asymmetry $\left(\mathrm{H} 6 \mathrm{a} ; \beta_{24}=-0.165, \mathrm{p}<0.05\right)$. Likewise, agency costs consists of the cost of auditing, preventing fraud, and the incentive costs are the causes for agencies to make more effort for their firm (Chong \& Eggleton, 2007; Lata \& Jiraphatthanaponsin, 2018; Marashdeh, 2014; Sprinkle, 2000). Hence, hypotheses 5 and 6a were supported. 


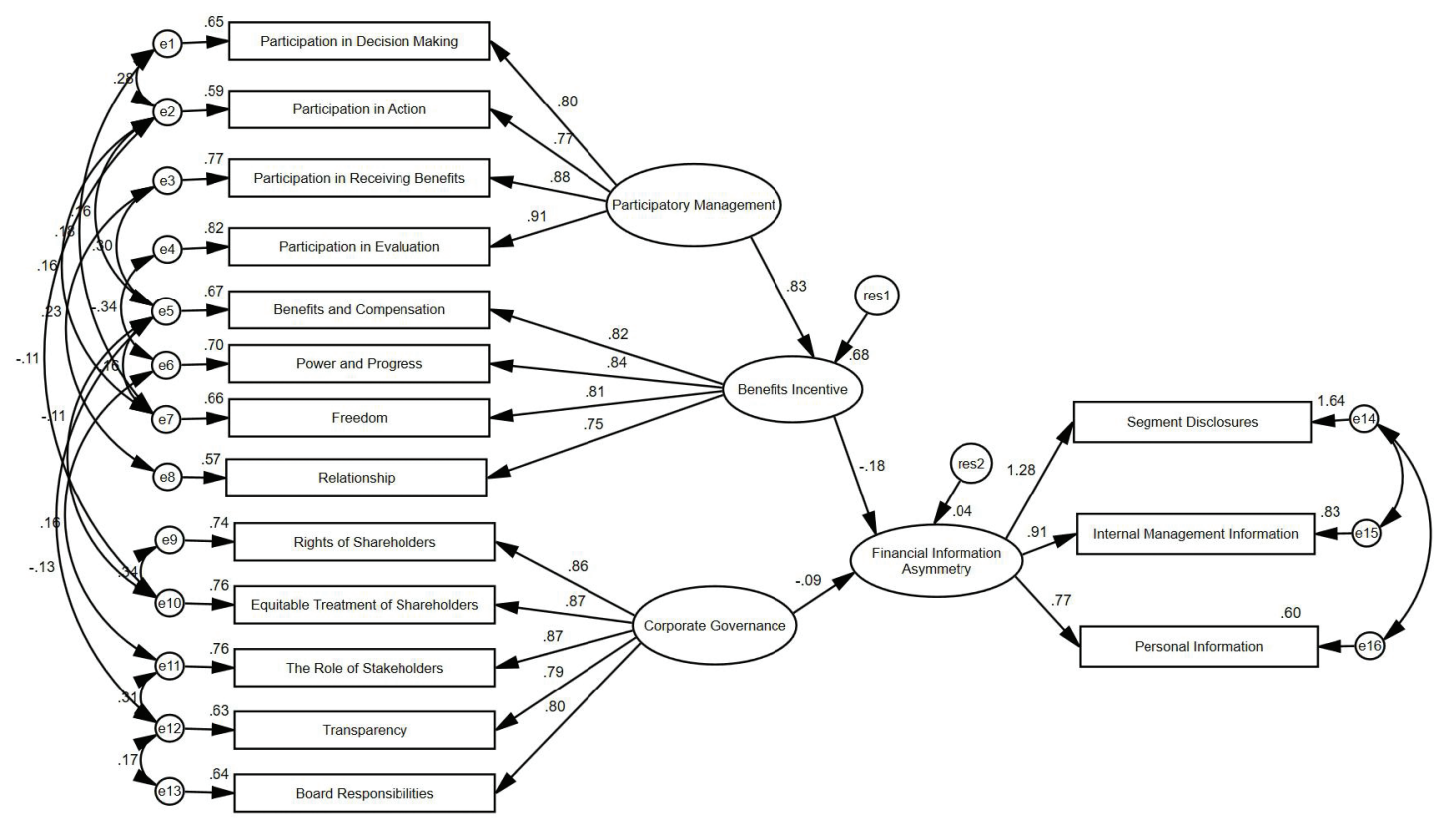

Chi-square $=104.459, \mathrm{df}=84, \mathrm{p}=0.065$

CMIN/DF $=1.244, \mathrm{GFI}=0.967, \mathrm{RMSEA}=0.025$

Figure 2: Structural Equations Model of The Influences of Participatory Management and Corporate Governance on The Reduction of Financial Information Asymmetry through Benefits Incentive

Table 4: Results of Total Effect (TE), Direct Effect (DE), and Indirect Effect (IE) between Latent Variables

\begin{tabular}{|c|c|c|c|c|c|c|c|}
\hline \multirow{2}{*}{ Exogenous } & \multirow{2}{*}{$\begin{array}{c}\text { Parameter } \\
\text { Coefficient } \\
\text { TE }\end{array}$} & \multicolumn{3}{|c|}{ Benefits Incentive } & \multicolumn{3}{|c|}{ Financial Information Asymmetry } \\
\hline & & IE & $\mathrm{DE}$ & TE & IE & DE & \\
\hline \multirow{2}{*}{ Participatory Management } & Unstandardized & $1.026^{* * *}$ & - & $1.026^{* * *}$ & $-0.212^{\star * *}$ & $-0.212^{* * *}$ & - \\
\hline & Standardized & $0.825^{\star * *}$ & - & $0.825^{\star * *}$ & $-0.145^{\star \star *}$ & $-0.145^{\star * *}$ & - \\
\hline \multirow{2}{*}{ Corporate Governance } & Unstandardized & - & - & - & $-0.097^{*}$ & - & $-0.097^{*}$ \\
\hline & Standardized & - & - & - & $-0.085^{*}$ & - & $-0.085^{*}$ \\
\hline \multirow{2}{*}{ Benefits Incentive } & Unstandardized & - & - & - & $-0.207^{* * *}$ & - & $-0.207^{* * *}$ \\
\hline & Standardized & - & - & - & $-0.176^{\star * *}$ & - & $-0.176^{* * *}$ \\
\hline \multicolumn{8}{|l|}{ Squared Multiple Correlations } \\
\hline \multicolumn{2}{|l|}{ Variables } & \multicolumn{3}{|c|}{ Benefits Incentive } & \multicolumn{3}{|c|}{ Financial Information Asymmetry } \\
\hline \multicolumn{2}{|l|}{$\mathrm{R}^{2}$} & \multicolumn{3}{|c|}{0.681} & \multicolumn{3}{|c|}{0.038} \\
\hline
\end{tabular}

\subsection{SEM Analysis}

The hypothesized model illustrated in Tables 4 and Figure 2 presents the results of the hypothesized relationships among participatory management, corporate governance, benefits incentive, financial information asymmetry (H7).
The sample $(n=388)$ was used to test the hypothesized relationships. The hypothesized model was tested using statistics indicating an acceptable model fit and was demonstrated to have a non-significant chi-square statistic $\left(\chi^{2}=104.459\right.$ with df $=84.065$; $\rho<0.065)$. 


\subsection{Goodness-of-Fit Test}

The results of Goodness of Fit Index (GFI), Adjusted Goodness of Fit Index (AGFI), Comparative Fit Index (CFI), and Normed Fit Index (NFI) exceed the threshold value of 0.90 and the hypothesized model revealed a good fit. A ratio of model fit statistics based on degrees of freedom below 3 indicates adequate model fit $\left(\chi^{2} / \mathrm{df}=1.244\right)$. Root Mean Square Error of Approximation(RMSEA) value reached an acceptable value of 0.025 . Specifically, the GFI, CFI, AGFI, and NFI values reached an acceptable value of 0.90 (0.967, 0.995, 0.947 , and 0.977 , respectively). The hypothesized model can be classified as closely fitting the empirical data.

To test Hypothesis 7 in table 4, the hypothesized model was tested using Amos, where the paths between participatory management, corporate governance, benefits incentive, and financial information asymmetry were estimated. The hypotheses regarding the relationships were tested based on the associated t-statistics. P-values were considered significant at the 0.05 , 0.01 , and 0.001 levels, respectively. Participatory management significantly and positively influenced $(\rho<0.001)$ the benefits incentive (Direct effect $=0.825$ ), and indirectly and negatively influenced the financial information asymmetry through benefits incentive with values (Indirect effect $=-0.145$ ), respectively. Benefits incentive significantly and negatively affected $(\rho<0.001)$ the financial information asymmetry with values (Direct effect $=-0.176$ ). Corporate governance significantly and negatively influenced $(\rho<0.05)$ the financial information asymmetry with values (Direct effect $=-0.085$ ). Figure 2 listed the results of the parameter estimates of the hypothesized model. Considering the standardized parameter estimates, the results of the hypothesized relationship were classified as significant. Thus, Hypothesis 7 was supported that participatory management and corporate governance are negatively associated with financial information asymmetry through benefits incentives as a partial mediator. It corresponds with agency theory to indicate that a high reliance on incentive-based compensation is more appropriate when high information asymmetry (Chong \& Eggleton, 2007; Gibbs et al., 2004).

\section{Conclusions}

This research had examined the influences of participatory management and corporate governance on the reduction of financial information asymmetry through benefits incentives as a mediator. There were 388 Thai-listed firms used as the unit of analysis and the key informants were executives of each firm. The results support that 1) participatory management and participation in evaluation had a negative influence on financial information asymmetry. 2) Corporate governance and the rights of shareholders had a negative influence on financial information asymmetry. 3) Benefits incentive was negatively associated with financial information asymmetry. All effects were significant at $\mathrm{p}<0.05$ and 0.10 , respectively. 4) The model's influences of participatory management, corporate governance on the reduction of financial information asymmetry through benefits incentive as mediator fit the empirical data.

Theoretical contributions of this research offered the new dimensions of participatory management, corporate governance, benefits incentives, financial information asymmetry measures, and attempted to investigate. This research confirmed Agency Theory that agency costs consist of the cost of auditing and preventing fraud, and the incentive costs, cause their agency's effort for the organization. Besides, this research supported stakeholder theory that a firm should create value for all stakeholders. The group of stakeholders including owners, shareholders, executives in holding firms, are those who are directly affected, either positively or negatively by an organization's actions such as fraud, corrupt behavior, information asymmetry, lack of transparency, and opportunistic behavior. This research provided a clear understanding of the structural equations model of the influences of participatory management and corporate governance on the reduction of financial information asymmetry through benefits incentives as a mediator.

Furthermore, directions for future research could examine the other mediator roles, such as using contemporary information technology, managerial relevant information, organizational structure, and cultural organization. Limitations of this research are Thai listed firms which are the sample because the biggest size in the business sector and higher efficiency, so future research could compare the firms in other industries and sectors. For managerial contribution to the business sector, this research provided guidelines and how to prevent fraud and participatory management, also corporate governance is important factors that decrease financial information asymmetry and improve their firm goal achievement. Thai listed firms must have the best participatory system and corporate governance mechanisms to help increase transparency, private information sharing, and trust each other more. Incentives of benefits and compensation and participation in evaluation reduced the opportunistic behavior of their agencies and create transparency.

\section{References}

Ajina, A., Sougne, D., \& Lakhal, F. (2015). Corporate disclosures, information asymmetry and stock-market liquidity in France. Journal of Applied Business Research, 31(4), 1223-1238.

Armstrong S. J., \& Overton T. S. (1977). Estimating non-response bias in mail surveys. Journal of Marketing Research. 14(3), 396-402.

Balkin, D. B., \& Gomez-Mejia, L. R. (1990). Matching compensation and organizational strategies. Strategic Management Journal, 11(2),153-169. 
Bhagat, S., \& Bolton, B. (2008). Corporate governance and firm performance. Journal of Corporate Finance, 14(3), 257-273.

Brazel, J. F., Jones, K. L., \& Zimbelman, M. F. (2009). Using nonfinancial measures to assess fraud risk. Journal of Accounting Research, 47(5), 1135-1166.

Chong, V. K., \& Eggleton, I. R. C. (2007). The impact of reliance on incentive-based compensation schemes, information asymmetry and organizational commitment on managerial performance. Management Accounting Research, 18, 312-342.

Chong, V. K., \& Law, M. B. (2016). The effect of a budget-based incentive compensation scheme on job performance. Journal of Accounting \& Organizational Change. 16, 590-613.

Connelly, L., Certo, T., Ireland, D., \& Reutzel, R. (2011). Signalling theory: A review and assessment. Journal of Management, 37(1), 39-67.

Cumming, D. J., Hornuf, L., Karami, M., \& Schweizer, D. (2020). Disentangling crowdfunding from fraud funding. Max Planck Institute for Innovation \& Competition Research Paper, (1609), 1-83. https://www.hec.ca/finance/Fichier/Schweizer2017. pdf

Fernandez, S., \& Moldogaziev, T. (2013). Using employee empowerment to encourage innovative behavior in the public sector. Journal of Public Administration Research and Theory, 23, 155-187. https://doi.org/10.1093/jopart/mus008

Freeman, R. E. (1984). Strategic Management: A Stakeholder Approach. Boston, MA: Pitman.

Gillan, S. L. (2006). Recent Developments in Corporate Governance: An overview. https:/edisciplinas.usp.br/ pluginfile.php/2731503/mod_resource/content/1/gillan2006. pdf

Hafez, S. (2015). The integration of six sigma and balanced scorecard in internal auditing. Integration, 6(18), 43-54.

Hair, J. F., Black, W. C., Babin, B., Anderson, R. E., \& Tatham, R. L. (2010). Multivariate Data Analysis. Englewood Cliffs, NJ: Pearson Education Inc.

Hedelin, B., Evers, M., Alkan-Olsson, J., \& Jonsson, A. (2017). Participatory modelling for sustainable development: Key issues derived from five cases of natural resource and disaster risk management. Environmental Science \& Policy, 76, 185196.

Jantadej, K., \& Wattanatorn, W. (2020). The effect of corporate governance on the cost of debt: Evidence from Thailand. Journal of Asian Finance, Economics and Business, 7(9), 283291. https://doi.org/10.13106/jafeb.2020.vol7.no9.283

Jensen, M. C., \& Meckling, W. H. (1976). Theory of the firm: Managerial behavior, agency costs and ownership structure. Journal of Financial Economics. 3(4), 305-360.

Joe, S. W. (2010). Assessing job self-efficacy and organizational commitment considering a mediating role of information asymmetry. The Social Science Journal, 47(3), 541-559.

Kimmich, C., Gallagher, L., Kopainsky, B., Dubois, M., Sovann, C., Buth, C., \& Brethaut, C. (2019). Participatory modeling updates expectations for individuals and groups, catalyzing behavior change and collective action in water-energyfood nexus governance. Earth's Future, 1337-1352. DOI: 10.1029/2019EF001311

Laan, S. (2009). The role of theory in explaining motivation for corporate social disclosures: Voluntary disclosure vs 'Solicited' Disclosures. Australasian Accounting Business and Financial Journal. 3(4), 12-29.

Lata, P. \& Jiraphatthanaponsin, T. (2018). Information asymmetry, incentive-based compensation plans, sustainable organizational commitment and managerial performance: Empirical evidence from industrial estate authority of Thailand. RMUTT Global Business and Economics Review, 13(2), 101-116.

Lata, P., \& Ussahawanitchakit, P. (2015). Management accounting system effectiveness and goal achievement: Evidence from automotive businesses in Thailand. The Business and Management Review, 7(1), 322-334.

Marashdeh, Z. M. S. (2014). The effect of corporate governance on firm performance in Jordan. Doctoral dissertation, University of Central Lancashire, UK.

Marc, M., Peljhan, D., Ponikvar, N., Sobota, A., \& Tekavcic, M. (2010). Determinants of integrated performance measurement systems usage: An empirical study. The Journal of Applied Business Research, 26(5), 63-75.

Markl-Davis, D. M., \& Brennan, N. M. (2007) Discretionary Disclosure Strategies in Corporate Narratives: Incremental Information or Impression Management? Journal of Accounting Literature, 26, 116-196.

Mori, N. (2010). Roles of stakeholders in strategic decision-making of microfinance organization. International Business and Economics Research, 9(7), 51-63.

Ndofor, H. A., Wesley, C. \& Priem, R. L. (2013). Providing CEOs with opportunities to cheat: The effects of complexity-based information asymmetries on financial reporting fraud. Journal of Management, 41, 1774-1797. https://journals.sagepub.com/ doi/10.1177/0149206312471395

Nel, G. F., Smit, E., \& Brummer, L. M. (2018). The link between internet investor relations and information asymmetry. South African Journal of Economic and Management Sciences, 21(1), $1-10$.

Neter, J., Wasserman, W., \& Kutner, M. H. (1989) Applied Linear Regression Models (2nd ed.). Homewood, IL: Richard D. Irwin, Inc.

Nunnally J. C., \& Bernstein I. H. (1994). Psychometric Theory. New York, NY: McGraw Hill.

Phornlaphatrachakorn, K., \& Na-Kalasindhu, K. (2020). Strategic management accounting and firm performance: Evidence from finance businesses in Thailand. Journal of Asian Finance, Economics and Business, 7(8), 309-321. https://doi. org/10.13106/jafeb.2020.vo17.no8.309

Phornlaphatrachakorn, K., \& Peemanee, J. (2020). Integrated performance measurement as a strategic management accounting approach: A case of beverage businesses in Thailand. 
Journal of Asian Finance, Economics and Business, 7(8), 247-257. https://doi.org/10.13106/jafeb.2020.vol7.no8.247

Randall, P. M., Saurage-Altenloh, S., \& Osei, E. T. (2020). The relationship between leadership ethics and organizational success: A global perspective. IGI Global, 106-137. DOI: 10.4018/978-1-7998-2377-3.ch005

Rezaee, Z. (2005). Causes, consequences, and deterrence of financial statement fraud. Critical Perspectives on Accounting, 16(3), 277-298. DOI: 10.1016/S1045-2354(03)00072-8

Rowley, T. J. (1997). Moving beyond dyadic ties: A network theory of stakeholder influences. Academy of Management Review, 22, 887-910.

Shagholi, R., Hussin, S., Siraj, S., Naimie, Z., Assadzadeh, F., \& Moayedi, F. (2010). Current thinking and future view: Participatory management a dynamic system for developing organizational commitment. Procedia-Social and Behavioral Sciences, 2(2), 250-254.

Signori, A. \& Vismara, S. (2018). Does success bring success? The post-offering lives of equity-crowdfunded firms. Journal of Corporate Finance, 50, 575-591.
Sprinkle, G. B. (2000). The effect of incentive contracts on learning and performance. The Accounting Review, 75(3), 299-326. https://doi.org/10.2308/accr.2000.75.3.299

Thorne, L., Mahoney, L., \& Manetti, G., (2014). Motivations for issuing standalone CSR reports: A survey of Canadian firms. Accounting, Auditing and Accountability Journal, 27(4), 686-714.

Tong, P. Y., \& Crosno, J. L. (2016). Are information asymmetry and sharing good, bad, or context dependent? A meta-analytic review. Industrial Marketing Management, 56, 167-180.

Ulibarri, N. (2018). Collaborative model development increases trust in and use of scientific information in environmental decision-making. Environmental Science \& Policy, 82, 136-142.

Wang, W., \& Yang, X. (2015). Does informal participation increase job satisfaction in public organizations? A study on civil servants in Beijing, China. Public Personnel Management, 44(3), 356374. DOI: $10.1177 / 0091026015586264$ 